\title{
Evaluating the Effectiveness of Asset Pricing Model before, during and after Financial Crisis 2008: Evidence from Karachi Stock Exchange
}

\author{
Waqar-ul-Hassan \\ Institute of Banking \& Finance, Bahauddin Zakariya University Multan, Pakistan \\ E-Mail: Waqar-hassan@ outlook.com
}

Zeeshan Hasnain

Institute of Banking \& Finance, Bahauddin Zakariya University Multan, Pakistan

Shahbaz Hussain

Faculty of Management \& Economics, Dalian University of Technology, China

Received: March 4, 2017 Accepted: April 11, 2017

doi:10.5296/ber.v7i1.11106 URL: https://doi.org/10.5296/ber.v7i1.11106

\begin{abstract}
The Study aims to explore the strength of arbitrage pricing model (APT) for determining stock returns of Karachi stock exchange (KSE) across three distinct and structured periods; before financial crisis period (2006-07), during financial crisis period (2008) and after financial crisis period (2009-10). The Study adopted descriptive statistics, Pearson correlation, linear regression, Random effect model for interpretation and execution of data. 253 financial and non-financial listed companies on KSE for the period of (2006-10) are considered as sample firms. Results of regression analysis indicated that models selected for the present study showed poor performance for measuring KSE returns. Independent variables showed significant behavior for measuring KSE returns in pre-financial crisis period; no statistical relationship for measuring KSE returns in during financial crisis period; insignificant nature for measuring KSE returns the post-financial crisis period. The Study has provided understandings about arbitrage theory applicability and financial crisis - 2008 impacts on KSE.
\end{abstract}

Keywords: Arbitrage pricing theory, Stock market, Financial crisis - 2008, Economic 
conditions and Panel analysis techniques

\section{Introduction}

Belgium, (1531) developed a first stock exchange in Antwerp, to engage government as well as individual business settlements. Establishment of stock exchanges across global markets; (Amsterdam stock exchange, 1602); (New York stock exchange, 1773) promote international business. Identification of "Securities Risk" limits the development of stock market because the return is the fundamental objective of investment. The Proactive behavior of investors against stock returns encourages the need for stock valuation theories. With the motive of ensuring safer investments; Markowitz, (1952) developed first stock valuation theory in the field of finance. Markowitz, (1952) stated that "Portfolio Construction" is the best possible way to secure healthier investments.

Markowitz, (1952) theory was acknowledged as a remarkable effort in the domain of corporate finance. Scholars from all over the world, indicated weaker performance of Markowitz, (1952) theory due to unavailability of quantitative analysis against portfolio construction. On the theoretical foundations of Markowitz, (1952), Sharpe, (1964) gave the concept of systematic risk $(\beta)$ in his theory Capital asset pricing model (CAPM). Co-developers of CAPM, including Linter, (1965) and Mossin, (1966) also validate the performance of Sharpe, (1964) theory. After the establishment of CAPM, researcher`s from rest of the world started analyzing its applicability on different stock markets with multiple quantitative techniques. Economist found Sharpe, (1964) theory as an incomplete valuation theory due to focusing only on $\beta$ and ignoring all other factors.

Ross, (1976) supported the findings of Linter, (1965); Mossin, (1966) by stating $\beta$ (systematic risk) as a poor estimator of securities returns. Keeping in mind the weaknesses of CAPM, Ross, (1976) developed arbitrage pricing theory (APT). Ross, (1976) introduced macroeconomic variables as an alternative to Sharpe, (1964) theory to measure stock returns. Scholars appreciated the performance of APT for predicting capital market returns, but still there exist a complexion regarding the selection of macroeconomic variables. Because Ross, (1976) only provide the concept of arbitrage pricing theory, no quantitative analysis has been provided for selection of macroeconomic variables.

It's the age of global village, now distances has been removed and all economies are on a single page for business purposes. Due to digital linkage among economies, financial distress of single stock market also affects the performance of other economies worldwide. In fiscal year (2008) U.S. banks faced liquidity risk; due to repayments default of mortgage loans, caused by sudden fall down of house prices up to $31.8 \%$. Globalization of economies put forward U.S. financial instability towards other capital markets, which originate global financial crisis (2008).

The collapse of Lehman Brothers on $14^{\text {th }}$ September 2008 signaled the starting of global financial crisis (2008). Developing economy including KSE has also been affected by the global financial crisis (2008). In the year $2008 \mathrm{KSE}$ index reached up to $15,737.32$ points, the highest level ever in the history of Pakistan. But due to the dramatic downfall in global 
financial markets, lowers down KSE index points badly which forcefully closed stock market for last quarter of the year 2008. KSE started its market operations with 7,014 index points only in the year 2009, global financial crisis dropped about $50 \%$ index points. Some researcher`s including; (Ilyas, 2014); (Ali \& Afzal, 2012) declared mixed effects of Global financial crisis 2008 on Pakistani capital markets.

\subsection{Study Objectives}

The purpose of this research is to explore the effectiveness of Ross, (1976) theory on three defined time frames; pre-global financial (2006-07); global financial crisis (2008) and post global financial crisis (2009-10). Objectives are given below which are defined to meet under certain selected statistical techniques and set of variables;

- To examine the impact of Inflation rate on KSE returns.

- To examine the impact of Unemployment rate on KSE returns.

- To examine the impact of Money supply on KSE returns.

- To examine the impact of Gross domestic production on KSE returns.

- To examine the impact of Exchange rate on KSE returns.

- To examine the impact of Exports on KSE returns.

\section{Literature Review}

Garba, (2014) studied inflation rate, interest rate, Gross national income, and the exchange rate of domestic currency for examining the efficacy of arbitrage pricing theory among Nigerian listed companies. 106 manufacturing companies were selected from Nigerian capital market with the help of stratified random sampling. The study gathered data for the period of 1999 to 2003 in order to reach statistical findings. Selected macroeconomic variables showed negative and insignificant behavior for measuring returns. Fazlia, et al., (2014) used OLS regression analysis to test the dynamic relationship between selected macroeconomic variables and listed Tehran companies. Study collected data for the period ranges from (1997-2007). Findings indicated that arbitrage pricing theory is not a good approach for studying Tehran market returns.

Iqbal, et al., (2012) adopted one-sample t-test to compare actual and predicted stock returns of $26 \mathrm{KSE}$ listed companies. The study collected five years (2004-2008) monthly data to put forward the designed objectives of the study. M1 (narrow money supply), the rate of inflation, exchange rate and oil prices were preferred under the head of arbitrage pricing theory. Findings indicated no statistical relationship among APT and securities returns. Zubairi and Farooq, (2011) conducted a study to inquire performance of CAPM and APT on 17 listed firms of Fertilizer and Oil \& Gas sectors of KSE. Results of regression analysis revealed the inadequate explanatory power of APT towards capital market returns.

Zafar, (2013) attempted to measure the impact of macroeconomic variables for measuring KSE returns by taking; domestic credit, value traded, real interest rate and FDI (foreign direct 
investment) as determinants of arbitrage pricing theory. Statistical software E-views is used for implementing descriptive, correlation and linear regression analysis in order to estimate the performance of independent variables for measuring the variance of the dependent variable. Findings of the present research work indicated the poor effectiveness of APT for examining KSE returns. Ibrahim and Musah, (2014) used johansen-juselius and vector error correction approaches understand the statistical relationship among Ghana stock exchange and arbitrage pricing theory. Results of regression analysis proved significant behavior of macroeconomic variables for measuring returns of Ghana stock exchange.

Yahyazadehfar and Babaie, (2012) used vector autoregression and Johansen Cointegration approaches on TSE (Tehran stock exchange) for the purpose of analyzing APT performance. The study took monthly data ranges from (2001-2011) to reach empirical findings. Results supported the positive association of house prices as well as the negative behavior of gold prices and interest rates for measuring Tehran stock returns. Hassan and Awais, (2015) studied the behavior of macroeconomic variables for measuring stock returns, across global financial markets. Findings proved multiple responses of macroeconomic variables for determining market returns in different economies.

\subsection{Research Gap}

Researchers from developed and developing economies; Ouma and Muriu, (2014); Harper and Jin, (2012); Sarwar et al. (2014); Butt, (2010); Khan et al. (2014) used arbitrage pricing theory for measuring stock returns. Global financial crisis (2008) has mixed effects on Pakistani capital markets; Ilyas, (2014); Ali and Afzal, (2012). Previous Pakistani researchers have not focused financial crisis periods for analyzing the performance of arbitrage pricing theory. The unemployment rate has a meaningful impact for measuring stock returns; Shiblee, (2009); Sirucek, (2012); Gertler et al. (1982). Earlier Pakistani scholars have not favored unemployment rate as a determinant of arbitrage pricing theory for measuring stock returns.

Most of the Pakistani researchers; Waliullah, (2010); Nishat and Shaheen, (2004); Rizwan and Khan, (2007); Attari and Safdar, (2013); Ahmad et al. (2015) prefer time series statistical techniques including; Autoregressive Heteroskedasticity models; Granger causality and Co-integration approaches to examine hypothetical relations. Hsiao, (2003) stated Panel data statistics as more efficient than time series. Only some earlier scholars in Pakistan adopted Panel data techniques including; Haque and Sarwar, (2012); Zaighum, (2014).

\subsection{Hypothesis Development}

For the purpose of testing proposed relationships, study developed following given hypothesis on the theoretical foundations of earlier studies;

H1: There exist a dual natured relationship between Inflation rate and KSE returns.

H2: There exist a dual natured relationship between Unemployment rate and KSE returns.

H3: There exist a dual natured relationship between Money supply and KSE returns.

H4: There exist a dual natured relationship between Gross domestic production and KSE 
returns.

H5: There exist a dual natured relationship between Exchange rate and KSE returns.

H6: There exist a dual natured relationship between Exports and KSE returns.

\subsection{Theoretical Framework}

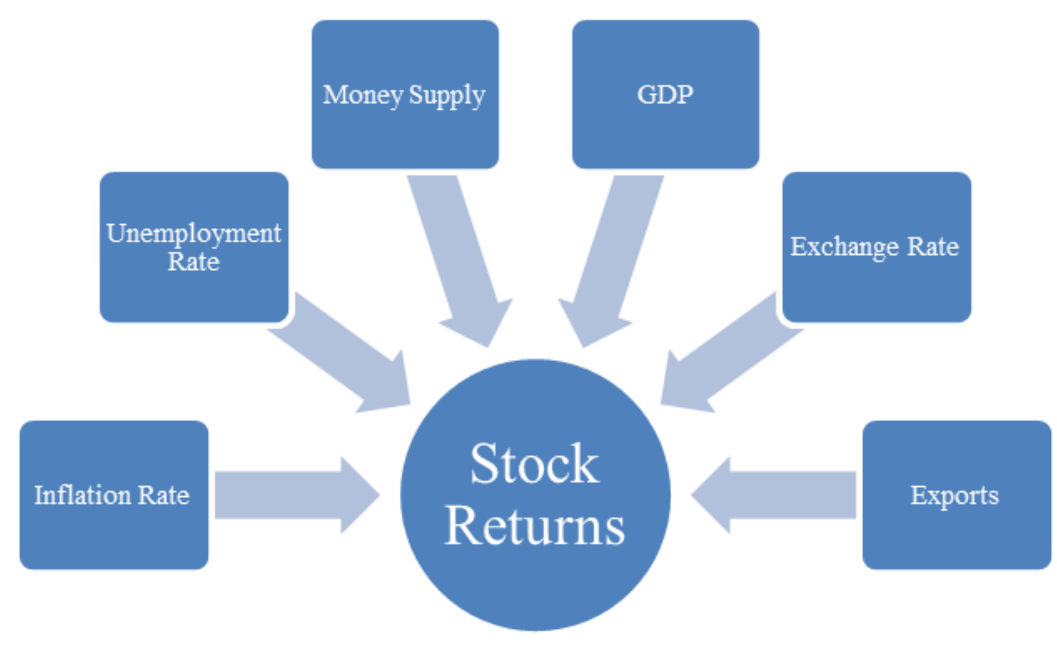

\subsection{Regression Model}

To test the performance of arbitrage pricing theory on KSE, the study developed following regression equation. The regression model is designed in statistical manners to fulfill the research objectives and hypothesized relationships.

$$
\mathrm{SR}=\alpha+\beta 1(\mathrm{INFR})+\beta 2(\mathrm{UEMPR})+\beta 3(\mathrm{MONSP})+\beta 4(\mathrm{GDP})+\beta 5(\mathrm{EXR})+\beta 6(\mathrm{X})+\varepsilon
$$

Whereas;

$$
\begin{array}{ll}
\mathrm{SR} & =\text { Stock returns } \\
\mathrm{INFR} & =\text { Inflation rate } \\
\mathrm{UEMPR} & =\text { Unemployment rate } \\
\mathrm{MONSP} & =\text { Money supply } \\
\mathrm{GDP} & =\text { Gross domestic production } \\
\mathrm{EXR} & =\text { Exchange rate } \\
\mathrm{X} & =\text { Exports } \\
\varepsilon & =\text { Error term }
\end{array}
$$

\section{Research Design}

\subsection{Population and Sample Selection}

One of the most productive and effective financial market of Pakistan named KSE is considered as a population of the present study. Five years panel data of 253 performing financial and non-financial firm`s ranges from 2006 to 2010 is selected as sample of the study. 


\subsection{Data Collection and Formation}

Data of CPI (inflation rate), M2 (money supply) and PKR/USD (exchange rate) is collected from IFS (international Financial Statistics) sourced from IMF (international monetary fund) data stream. Furthermore, World bank data bank is favored for gathering statistics of the unemployment rate. Data of exports and Gross domestic production is obtained from official website of Pakistan bureau of statistics. Gathered data against all selected variables of the study are arranged in Panel data formation for further analysis.

\subsection{Econometric Techniques}

Descriptive statistics, Pearson correlation, linear regression and Random effect models are preferred to make an analysis of this study. Statistical package STATA is used to for implementation of models and techniques to test the hypothetical relationships.

\section{Results and Discussion}

\subsection{Descriptive Statistics}

A study carried out descriptive statistics containing mean and standard deviation to demonstrate the temporal properties of selected variables. Values of descriptive statistics are given in table 4.1. Statistics indicating that studied data sets are normal, however, all variables showed little bit variations at their desired levels.

Table 1. Descriptive statistics

\begin{tabular}{|l|c|c|c|c|c|}
\hline Variable & Obs. & Mean & Standard Deviation & Minimum & Maximum \\
\hline SR & 1,265 & 0.0456 & 0.5983 & -0.9382 & 4.786 \\
\hline INFR & 1,265 & 0.1266 & 0.0466 & 0.076 & 0.2029 \\
\hline UEMPR & 1,265 & 0.0176 & 0.0011 & 0.0163 & 0.0195 \\
\hline MONSP & 1,265 & 4.8300 & 8.3500 & 3.6700 & 6.1200 \\
\hline GDP & 1,265 & 202.12 & 8.5846 & 188.88 & 213.71 \\
\hline EXR & 1,265 & 71.664 & 10.345 & 60.271 & 85.193 \\
\hline X & 1,265 & 1.2900 & 2.4800 & 9.9200 & 1.6400 \\
\hline
\end{tabular}

\subsection{Pearson Correlation Analysis}

The study employed Pearson correlation analysis to examine the relationship between selected variables. Outputs of Pearson analysis are disclosed in table 4.2. The rate of unemployment and exchange rate seems to be highly correlated with exports and Gross domestic production. M2 (money supply) presented high correlation for exchange rate and exports. Unemployment rate indicated negligible relation for exports, M2 (money supply) and rate of exchange. GDP declared the low amount of correlation towards the rate of exchange, M2 (money supply) and exports. Inflation highlighted moderate correlation for M2 (money supply), the rate of exchange and unemployment. Moderate correlation is presented for the rate of exports and Gross domestic production. 
Table 2. Pearson correlation analysis

\begin{tabular}{|l|c|c|c|c|c|c|c|}
\hline & SR & INFR & UEMPR & MONSP & GDP & EXR & X \\
\hline SR & 1 & & & & & & \\
\hline INFR & -0.2312 & 1 & & & & & \\
\hline UEMPR & -0.0736 & -0.4641 & 1 & & & & \\
\hline MONSP & 0.0443 & 0.4284 & -0.1248 & 1 & & & \\
\hline GDP & -0.0274 & 0.6691 & -0.8049 & 0.3942 & 1 & & \\
\hline EXR & -0.0331 & 0.5231 & 0.0091 & 0.9421 & 0.2206 & 1 & \\
\hline X & -0.0662 & 0.6399 & -0.0818 & 0.9493 & 0.3979 & 0.9749 & 1 \\
\hline
\end{tabular}

\subsection{Regression Analysis}

The most common and renowned panel analysis techniques are Random and fixed effect models. Haque and Sarwar, (2012) suggested Hausman test for making comparison among random and fixed effect models. The present study also applied Hausman test which favored Random effect model as a suitable technique for this study. Results of regression analysis are given in table 4.3 .

Table 3. Regression results

\begin{tabular}{|c|c|c|c|c|}
\hline Models & $\begin{array}{c}\text { Gradual } \\
\text { Regressions }\end{array}$ & $\begin{array}{c}\text { Gradual } \\
\text { Regressions }\end{array}$ & $\begin{array}{c}\text { Gradual } \\
\text { Regressions }\end{array}$ & $\begin{array}{c}\text { Full } \\
\text { Model }\end{array}$ \\
\hline Periods & Before Crisis & During Crisis & After Crisis & Whole Period \\
\hline \multirow[t]{2}{*}{ Constant } & & & & $0.003 *$ \\
\hline & & & & $(-2.8161)$ \\
\hline \multirow[t]{2}{*}{ INFR } & $0.000 *$ & Omitted & 0.242 & Omitted \\
\hline & $(-152.69)$ & & $(-25.945)$ & \\
\hline \multirow[t]{2}{*}{ UEMPR } & $0.000 *$ & Omitted & 0.242 & Omitted \\
\hline & $(-164.68)$ & & $(-79.460)$ & \\
\hline \multirow[t]{2}{*}{ MONSP } & $0.000 *$ & Omitted & 0.242 & $0.000 *$ \\
\hline & )$(6.7900)$ & & $(-7.4600)$ & )$(6.6700)$ \\
\hline \multirow[t]{2}{*}{ GDP } & $0.000 *$ & Omitted & 0.242 & $0.016 * *$ \\
\hline & )$(0.0295)$ & & $(-0.0061)$ & )$(0.0093)$ \\
\hline \multirow[t]{2}{*}{ EXR } & $0.000 *$ & Omitted & 0.242 & $0.001 *$ \\
\hline & )$(1.0458)$ & & $(-0.0171)$ & )$(0.0448)$ \\
\hline \multirow[t]{2}{*}{$X$} & $0.000 *$ & Omitted & 0.242 & $0.000 *$ \\
\hline & )$(1.2300)$ & & $(-3.0100)$ & $(-4.2400)$ \\
\hline Regression Technique & REM & REM & REM & Multiple Linear \\
\hline R-Square & 0.149 & 0.000 & 0.002 & 0.128 \\
\hline $\mathrm{N}$ & 506 & 253 & 506 & 1,265 \\
\hline \multicolumn{2}{|c|}{ Notes: ${ }^{*} \mathrm{p}<0.01 ; * * \mathrm{p}<0.05 ; * * * \mathrm{p}<0.1$} & & & \\
\hline
\end{tabular}


Inflation rate presented negative and significant behavior for causing KSE returns in before financial crisis period (2006-07) and showed negative insignificant attitude in after financial crisis period (2009-10). Significant as the well insignificant behavior of inflation rate for measuring stock returns proved the dual natured relationship between inflation rate and KSE returns. Increase in inflation rate decreases stock returns, describing that devaluation in national currency adversely affects the financial health of sampled firms, which resulted in lower stock returns.

Unemployment rate indicated inverse and significant attitude for measuring stock returns in before financial crisis period (2006-07) and presented negative insignificant behavior in after financial crisis period (2009-10). Significant along with the insignificant behavior of the unemployment rate for determining stock returns proved the dual natured relationship between unemployment rate and KSE returns. Increase in unemployment rate decreases stock returns, explaining that increase in a number of unemployed persons; lowers the purchasing power and promote inflation within the economy, which devalues stock returns.

The Higher amount of money supply within the economy indicated that purchasing capacity and demands for goods \& services raised due to having handsome money on individual's hands. Demand for goods provides a way forward for optimal utilization of natural resources, which ultimately leads toward higher employed person's ratio and industrial production within national boundaries. Money supply showed positive relationship for stock returns in before financial crisis period (2006-07) due to the low rate of unemployed persons. Furthermore, a negative relationship is found between money supply and stock returns due to the high rate of unemployed persons.

GDP symbolizes summarized industrial productions across national boundaries, greater the level of firm`s production higher will be the number of employed persons within the economy. Which ultimately ensure firm`s financial viability including reserves and profitability. During before financial crisis period (2006-07) there exist a positive relationship between GDP and KSE returns due to low inflation and unemployment rate. The negative association between GDP and stock returns in after financial crisis period (2009-10) is due to high amount of unemployment and inflation rate.

Exchange rate showed positive as well as negative behavior towards stock returns. Incremental change in exchange rate played a dual natured role towards the economy. Its effect may be positive because lower exchange rate resulted in smart production, which enhances exports volume by attracting foreign business community. In before financial crisis period (2006-07), KSE returns and the exchange rate is positively related to one another due to greater net exports. However there exist negative association among KSE returns and exchange rate in after financial crisis period (2009-10) due to lower net exports.

Industrial production promotes exports volume within the country, which is fruitful for enhancing individuals per capita income and number of employed persons. Demand for goods and services directly linked to the rate of employment. In a nutshell, we can state that volume of exports causes the rate of inflation by providing significant difference among supply and demand of goods. In before financial crisis period (2006-07) there exist a positive 
relationship between exports and stock returns due to the low inflation rate, on the other hand, the negative association found among exports and stock returns in after financial crisis period (2009-10) due to the high inflation rate.

\section{Conclusion Indicating Research Contribution to Earlier Studies}

Regression equation presented 0.149, 0.000, 0.002 and 0.128 R-square values in before global financial crisis period; during global financial crisis period (2008); after global financial crisis period (2009-10) and whole period (2006-10) respectively. Tandon and Malhotra, (2012) resulted 0.116; Khan et al. (2012) indicated 0.094; Zubairi and Farooq, (2011) measured 0.003; Saeed and Akhter, (2012) highlighted 0.105; William and Lemaistre, (2014) declared 0.091, R-square values for measuring stock returns.

The present study contributes to earlier Pakistani studies by demonstrating that referencing to foreign researchers; Shiblee, (2009); Sirucek, (2012); Gertler et al. (1982), the unemployment rate has meaningful significant behavior for examining KSE returns. Study encourage the earlier studies; Ilyas, (2014); Ali and Afzal, (2012) by stating mixed adverse effects of global financial crisis (2008) on Pakistani capital markets. Findings of the study supported; Malik et al, (2016); Rahim, (2013); Zaighum, (2014); Butt and Rehman, (2010); Ali et al. (2014); Hasan and Nasir, (2008); Siddiqui, (2014); Mohammad et al. (2009) by declaring arbitrage pricing theory as poor model for determining stock returns of KSE.

\section{References}

Ahmad, A. U., Abdullah, A., Abdullahi, A. T., \& Muhammad, U. A. (2015). Stock Market Returns and Macroeconomic Variables in Nigeria: Testing for Dynamic Linkages with a Structural Break. Scholars Journal of Economics. Business and Management, 2(8A), 816-828.

Ali, P. I., \& Akujuobi, A. B. C. (2014). Empirical Analysis of the Relationship between Stock Market Returns and Macroeconomic Indicators in Nigeria. Research Journal of Finance and Accounting, 5(14), 34-40.

Ali, R., \& Afzal, M. (2012). Impact of global financial crisis on stock markets: Evidence from Pakistan and India. Journal of Business Management and Economics, 3(7), 275-282.

Attari, M. I., \& Safdar, L. (2013). The Relationship between Macroeconomic Volatility and the Stock Market Volatility: Empirical Evidence from Pakistan. Pakistan Journal of Commerce and Social Sciences, 7(2), 309-320.

Butt, B. Z. (2010). Economic Forces And Stock Market Returns: A Cross Sectroal Study Testing Multifactor Model. P.hd Thesis in Management Sciences; Foundation University Islamabad, Pakistan.

Butt, B. Z., \& Rehman, K. U. (2010). Economic Exposure of Stock Returns in an Emerging Stock Market. World Applied Sciences Journal, 9(3), 322-332.

Fazlia, S., Shlan, S. S., Radsar, S., \& Radsar, M. (2014). An investigation on the relationship between arbitrage and macro-economic indicators: A case study of Tehran Stock Exchange. 
Management Science Letters, 4, 635-640. https://doi.org/10.5267/j.ms1.2014.2.032

Garba, A. (2014). Impact of Macroeconomic Factors on Common Stock Returns: A Study of Listed Manufacturing Firms in Nigeria. European Journal of Business and Management, 6(13), 140-150.

Gertler, Earl, L., M., \& Grinols. (1982). Unemployment, Inflation, and Common Stock Returns. Journal of Money, Credit \& Banking; Ohio State University Press, 14(2), 216. https://doi.org/10.2307/1991640

Haque, A., \& Sarwar, S. (2012). Macro-Determinants of Stock Return in Pakistan. Middle-East Journal of Scientific Research, 12(4), 504-510.

Harper, A., \& Jin, Z. (2012). Stock Returns and Macroeconomics Factors: An Examination of the Indonesian Domestic Economy. International Research Journal of Applied Finance, 3(4), 426-434.

Hasan, A., \& Nasir, Z. M. (2008). Macroeconomic Factors and Equity Prices: An Empirical Investigation by Using ARDL Approach. The Pakistan Development Review, 47(4 Part II), 501-513.

Hassan, W. U., \& Awais, M. (2015). Behavior of Microeconomic Forces to Predict Stock Returns: Empirical Evidence from Global Financial Markets. International Multidisciplinary Research Journal, European Academic Research, 3(3), 3674-3698.

Hsiao, C., (2003), Analysis of Panel Data, second edition, Cambridge University Press. https://doi.org/10.1017/CBO9780511754203

Ibrahim, M., \& Musah, A. (2014). An Econometric Analysis of the Impact of Macroeconomic Fundamentals on Stock Market Returns in Ghana. Research in Applied Economics, 6(2), 47-72. https://doi.org/10.5296/rae.v6i2.5146

Ilyas, M. (2014). Financial Crisis of 2008 and Performance of Firms (A Case of Listed Firms on Karachi Stock Exchange). Journal of Economics and Sustainable Development, 5(24), 182-184.

Iqbal, N., Khattak, S. R., Khattak, M. A., \& Ullah, I. (2012). Testing the Arbitrage Pricing Theory on Karachi Stock Exchange. Interdisciplinary Journal of Contemporary Research In Business, 4(8), 839-853.

Khan, W. A., Javed, M. A., Shahzad, N., Sheikh, Q., Saddique, S., Riaz, M., \& Batool, S. (2014). Impact of Macroeconomics variable on the Stock Market index; A Study from Pakistan. International Journal of Accounting and Financial Reporting, 4(2), 258-272. https://doi.org/10.5296/ijafr.v4i2.6483

Khan, Z., Khan, S., Rukh, L., Imdadullah, \& Rehman, W. U. (2012). Impact Of Interest Rate, Exchange Rate And Inflation On Stock Returns Of KSE 100 Index. International Journal of Economic Research, 3(5), 142-155.

Lintner, J. (1965). The Valuation of Risk Assets and the Selection of Risky Investments in 
Stock Portfolios and Capital Budgets. The Review of Economics and Statistics, 47(1), 13-37. https://doi.org/10.2307/1924119

Malik, M. S., Awais, M., ul Hassan, W., Hayat, F., Hussain, S., \& Khursheed, A. (2016). Dual Perspective of Inflation toward Market Development. International Journal of Economics and Finance, 8(3), 225. https://doi.org/10.5539/ijef.v8n3p225

Markowitz, H. (1952). Portfolio Selection. The Journal of Finance, 7(1), 77-91. https://doi.org/10.1111/j.1540-6261.1952.tb01525.x

Mohammad, S. D., Hussain, A., Jalil, M. A., \& Ali, A. (2009). Impact of Macroeconomics Variables on Stock Prices: Emperical Evidance in Case of KSE (Karachi Stock Exchange). European Journal of Scientific Research, 38(1), 96-103.

Mossin, J. (1966). Equilibrium in a Capital Asset Market. Econometrica, 34(4), 768-783. https://doi.org/10.2307/1910098

Nishat, M., \& Shaheen, R. (2004). Macroeconomic Factors and the Pakistani Equity Market. The Pakistan Development Review, 43(4 Part II), 619-637.

Ouma, W. N., \& Muriu, D. P. (2014). The Impact of Macroeconomic Variables on Stock Market Returns in Kenya. International Journal of Business and Commerce, 3(11), 01-31.

Rahim, S. (2013). Impact of Macroeconomic Variables on Stock Returns of Chemical Industry in Pakistan. NUML Journal of Management \& Technology, 8(1), 31-43.

Rizwan, M. F., \& Khan, S. U. (2007). Stock Return Volatility in Emerging Equity Market (Kse): The Relative Effects of Country and Global Factors. International Review of Business Research Papers, 3(2), 362 - 375.

Ross, S. A. (1976). The Arbitrage Theory of Capital Asset Pricing. Journal of Economic Thoery, 13, 341-360. https://doi.org/10.1016/0022-0531(76)90046-6

Saeed, S., \& Akhter, N. (2012). Impact of Macroeconomic Factors on Banking Index in Pakistan. Interdisciplinary Journal of Contemporary Research in Business, 4(6), 1200-1218.

Sarwar, A., Aftab, M. H., Khan, R. A., \& Qureshi, H. A. (2014). Impact Of Macroeconomic Factors On The Stock Index: A Case Study Of Pakistan. Science International (Lahore), 26(5), 2595-2601.

Sharpe, W. F. (1964). Capital Asset Prices: A Theory of Market Equilibrium under Conditions of Risk. The Journal of Finance, 19(3), 425-442.

https://doi.org/10.1111/j.1540-6261.1964.tb02865.x

Shiblee, L. (2009). The Impact of Inflation, GDP, Unemployment, and Money Supply on Stock Prices. Technical Report, Arab Bank - Syria. https://doi.org/10.2139/ssrn.1529254

Siddiqui, M. M. (2014). Oil Price Fluctuation and Stock Market Performance-The Case of Pakistan. Journal of International Business and Economics, 2(1), 47-53.

Sirucek, M. (2012). Macroeconomic variables and stock market: US review. International 
Journal of Computer Science and Management Studies, 2(2).

Tandon, K., \& Malhotra, N. (2012). Examining The Relationship Between Stock Prices And Macroeconomic Variables - Empirical Evidence From India. International Journal of Applied Financial Management Perspectives, 1(1), July -September.

Waliullah. (2010). Financial Liberalization and Stock Market Behaviour in an Emerging Market - A Case Study of Pakistan. International Journal of Business and Social Science, 1(3), 75-86.

William, \& Lemaistre, D. J. (2014). Validity Of Arbitrage Pricing Theory In Indonesia Stock Market. Technical Report; Binus University Jakarta, Indonesia.

Yahyazadehfar, M., \& Babaie, A. (2012). Macroeconomic Variables and Stock Price: New Evidence from Iran. Middle-East Journal of Scientific Research, 11(4), 408-415.

Zafar, M. (2013). Determinants of Stock Market Performance in Pakistan. Interdisciplinary Journal of Contemporary Research in Business, 4(9), 1017-1026.

Zaighum, I. (2014). Impact of Macroeconomic Factors on Non-financial firms' Stock Returns: Evidence from Sectorial Study of KSE-100 Index. Journal of Management Science, 1(1), 35-48. https://doi.org/10.20547/jms.2014.1401103

Zubairi, H. J., \& Farooq, S. (2011). Testing The Validity Of CAPM And APT In The Oil, Gas And Fertilizer Companies Listed On The Krachi Stock Exchange. Pakistan Business Review, 439-458.

\section{Copyright Disclaimer}

Copyright for this article is retained by the author(s), with first publication rights granted to the journal.

This is an open-access article distributed under the terms and conditions of the Creative Commons Attribution license (http://creativecommons.org/licenses/by/3.0/). 